\title{
Algology and algologists at Bowling Green, a short history
}

\author{
Rex L. Lowe $\mathrm{e}^{1,2, *}$ \\ ${ }^{1}$ Department of Biological Sciences, Bowling Green State University, Bowling Green, Ohio, 43403, USA \\ ${ }^{2}$ University of Michigan Biological Station, Pellston, Michigan, 49762, USA \\ (*Author for correspondence: E-mail: LOWE@BGNET.BGSU.EDU)
}

Key words: algae, periphyton, ecology, environment, assessment, systematics

\begin{abstract}
This paper summarizes the past 34 years of studies of algae by Rex Lowe and his students and collaborators at Bowling Green State University, Ohio, USA. Sixty-two students have received graduate degrees in this academic program focusing on systematics, ecology and environmental assessment. The taxonomic/ floristic research initially focused on northern Ohio streams but is now continental to international in scope focusing on the algal flora of the Great Smoky Mountains National Park and on the South Island of New Zealand. Ecological research has focused on factors that regulate the structure and function of benthic algae. Variables that have been examined include abiotic resources (nutrients and light), grazers and physical disturbance. Studies on environmental assessment have focused primarily on the impact of pointsource loads of chemicals into water bodies.
\end{abstract}

\section{Introduction}

I was surprised, humbled and greatly honored upon learning of my students' plans to organize a celebration in 2003 to recognize, summarize and reflect on studies of algae undertaken at Bowling Green State University during the past 34 years. When asked to write the introductory chapter to a collection of scientific papers contributed by former academic advisees and research collaborators I decided instead to write about the former students themselves and how their ambitions and interests helped shape my own. Sixty-two graduate students matriculating through the Algal Ecology Laboratory at Bowling Green State University coinciding with my 60th birthday seems an appropriate time for retrospection. The theme of this special volume is "Benthic algae: Their Roles in Aquatic Ecology, Systematics, and Environmental Assessment." Although these subdisciplines encompass an expansive continuum of questions of scientific interest it has become increasingly clear that ecology and systematics are inseparable (Kociolek \& Stoermer, 2001). One cannot accurately describe species interactions and environmental relationships if the species are unknown. This issue is particularly critical when attempting to extrapolate insights gained from research to other algal communities separated by time (paleolimnolgy) or space (biogeography). In addition, the biological species concept has been difficult to apply to algae given their cryptic sexual behavior. Indeed, most algal "species" have not been observed reproducing sexually. Thus, morphology and increasingly ecology are being employed in algal species concepts. The inseparability of ecology and systematics has been extended to the application of algal communities in environmental assessment (Bahls, 1973, 1974; Descy, 1979; Stevenson \& Lowe, 1986; Morgan, 1987; Biggs, 1989; Dixit et al., 1992; Lowe \& Pan, 1996; Stevenson \& Pan, 1999). Accurate species identification is essential for accurate environmental assessment whether the algal communities are modern or fossil. 
Students in the algal graduate program over the past three decades pursued a continuum of interests in the three sub disciplines (systematics, ecology and environmental assessment). This research continuum led to close and fertile interstudent collaborations that continue today. Many of the students that matriculated through the program are at the forefront of the field today. I am extremely proud of them. I will divide my summary of these research pursuits into the three sub disciplines, while recognizing their interrelatedness.

\section{Systematics and morphology}

Our initial interest in the algae laboratory was documenting the local flora of northwest Ohio, USA. Bowling Green rests in an area formerly known as "The Great Black Swamp," a glacial remnant of Lake Erie (Kaatz, 1955). Streams in northwest Ohio are all low-gradient in nature and strongly influenced by agricultural practices. The Portage River system was studied by McCullough (1971), Jackson (1975) and Rohr (1977). Stevenson (1976), Kline (1975) and Pryfogle (1976) investigated algal communities in the Sandusky River. Acker (1977), Fisher (1980) and Lamb (1983) researched the algae of the Maumee River. The algal flora of these rivers is typical of sluggish, nutrient-rich water. Phytoplankton was typically dominated by small centric diatoms in the genera Cyclotella, Stephanodiscus and Thalassiosira (Lowe \& Crang, 1972; Busch, 1974; Lowe, 1975; Lowe \& Busch, 1975; Lowe \& Kline, 1976; Kline \& Lowe, 1976). The benthic algal flora of these sediment-rich rivers was dominated by epipelic species typical of low-gradient streams (Jackson \& Lowe, 1978; Kociolek et al., 1983).

Following extensive research on northwestern Ohio streams we initiated studied in the southeastern United States in the late 1970s. Camburn (1977) wrote a thesis on the diatom flora of Long Branch Creek in South Carolina that led to his substantial and profusely-illustrated manuscript (Camburn et al., 1978) in which he described eleven new diatom taxa form a flora of 268 total taxa. The appearance of so many undescribed taxa provided incentive for continued taxonomic and floristic research in the southeast. Kociolek (1982) and Keithan (1983) both conducted their graduate research in the
Great Smoky Mountains National Park. While Kociolek focused on taxonomic issues documenting the diatom flora of selected streams including the description of five new taxa (Kociolek \& Lowe, 1983; Lowe \& Kociolek 1984), Keithan was ecologically focused examining the role of current in structuring benthic algal communities (Keithan \& Lowe, 1985). This initial research in the Great Smoky Mountains National Park made our current large-scale algal biodiversity project which is part of a larger all-taxa biodiversity inventory possible (Sharkey, 2001; Gomez et al., 2003; Potapova et al., 2003; Johansen et al., 2004).

Taxonomic and floristic research in our laboratory took a more international approach in the 1990s. In collaboration with Barry Biggs at The National Institute for Water and Atmospheric Research while on a sabbatical leave in New Zealand, we observed that diatoms from many local habitats were not easily identified using taxonomic literature from the northern hemisphere. This led to a more intensive investigation into endemic New Zealand diatom species (Sabbe et al., 2001; Kilroy et al., 2003) that is still in progress. In addition to our New Zealand algal floristic work, the arrival of Sophia Passy in Bowling Green enabled us to pursue taxonomic/floristic work on diatoms from Bulgaria (Passy \& Lowe, 1994) and from South Africa (Passy-Tolar et al., 1997). Taxonomy and floristics continue to one of the central areas of research interest in the Bowling Green algae laboratory.

\section{Ecology}

The major focus of research activities of students matriculating through the graduate program in the algology laboratory at Bowling Green has, not surprisingly, centered on ecology. Because algal assemblages are spatially compact and respond to environmental variables relatively quickly, they are ideal subjects for students wanting to pursue a research question addressing community ecology in a limited period of time. Also, algae stand at the interface of the abiotic and biotic components of the ecosystem converting inorganic minerals to organic compounds. Thus, algal community structure, function and dynamics are potentially 
strongly regulated by abiotic resources and/or consumers and/or disturbance. This complexity is increased when one considers that algal assemblages are composed of a large numbers of species, with species richness often exceeding 100, providing an incredibly complex system for investigation.

Initial investigations were descriptive in nature, generating correlative data sets (Lamb \& Lowe, 1981; Lowe et al., 1982; Millie \& Lowe, 1983; Belanger et al., 1985). Bruno (1978) and Kingston (1980) researching benthic algal assemblages in an Ohio bog lake and Grand Traverse Bay, Lake Michigan were among the early researchers applying multivariate techniques in the analysis of algal communities (Bruno \& Lowe, 1980; Kingston et al., 1983). Kingston's research documented a benthic diatom assemblage living below the maximum penetration of the summer thermocline in Lake Michigan that was highly diverse and structurally stable through seasons. In contrast, he found that shallower benthic assemblages displayed strong seasonal variability in structure. Kingston's is one of the few data sets detailing this important deep benthic community in Lake Michigan.

Passy (1997) applied multivariate analyses to seasonal benthic algal community structure in the Mesta River, Bulgaria. From detailed collections of epilithon, epiphyton, epipelon, epipsammon and plocon across nutrient gradients she was able to define subsets of taxa based on both nutrient and microhabitat preferences (Passy-Tolar et al., 1999).

Miller (1983) and Krejci (1985) examined algal distribution patterns at a much finer scale than had been customary in algal ecology. Both students focused on epipsammic diatom communities. Miller investigated the role of micro-topography of sand grains and its influence on diatom distribution (Miller et al., 1987). Her investigation demonstrated habitat partitioning among diatoms on sand grains with prostrate diatoms normally occupying depressions while the ridges were occupied by diatom taxa with relatively short and stout flexible stalks that enabled these forms to better resist crushing during sand drifting events. Krejci examined seasonal phenology of epipsammon in a stable spring-fed brook (Krejci \& Lowe, 1987a) documenting, among other findings a preferred temperature range for the spring Meridion bloom
(Krejci \& Lowe, 1987b). Krejci also documented the role of sand grain mineralogy using scanning electron microscopy (SEM) and x-ray energy dispersive spectroscopy technology for sand grain elemental analysis as an influence on diatom colonization. Krejci determined that stalked diatoms preferred quartz sand grains, which comprised $65 \%$ of the grains he examined. In contrast, motile prostrate diatoms showed no preference between quartz and feldspar sand grains (Krejci \& Lowe, 1986). Krejci and Miller's research was a strong confirmation that algae significantly exploited habitat variability at microscopic scales. Insights into microalgal ecology must focus at the appropriate scale.

Greenwood et al. (1999) also employed SEM to examine the distribution and behavior of diatoms moving through sediments (endopelic). This littleexplored microhabitat still holds many interesting mysteries on algal behavior and the interface with endopelic consumers.

\section{Abiotic resources}

Fairchild's (Fairchild \& Lowe, 1984) development of a means of manipulating nutrients in-situ using clay flower pots stimulated many students to manipulate abiotic variables while investigating interspecific interactions among benthic algal populations (Carrick, 1985; Luttenton, 1989; Marks, 1990; Pillsbury, 1993; Pan, 1993). Nitrogen or phosphorus were found to be a limiting nutrient for periphyton populations in most of the lotic and lentic habitats investigated (Fairchild et al., 1985; Lowe et al., 1986). Although Carrick \& Lowe (1988) found some benthic algal populations to be silicon limited when not allowed contact with quartz sand substrate by supplying nitrogen and phosphorus in a silicon-free medium. Carrick's major contribution resulted from research he conducted in northern Lake Michigan demonstrating that different benthic algal populations are limited by different resources and that it is incorrect to assume that algae are limited by a single resource as if they were a population rather than an assemblage of many populations (Carrick et al., 1988). DeYoe et al. (1992) demonstrated the sensitivity of some taxa to nitrogen/phosphorus ratios in the environment demonstrating that the numbers of endosymbiotic nitrogen-fixing 
cyanobacteria within the diatom Rhopalodia is partially a function of the external $\mathrm{N} / \mathrm{P}$ ratio.

Fairchild's nutrient diffusing substrate technique was also employed to understand how $\mathrm{pH}$ differences in aquatic ecosystems can impact nutrient limitation. Keithan et al. (1988) investigated periphyton species response to nitrogen and phosphorus manipulation in a culturally acidified stream while Carrick manipulated nutrients along a natural $\mathrm{pH}$ gradient in a northern Michigan lake (Carrick \& Lowe, 1989).

Pillsbury (1993) investigated light resources examining both quantity and quality of light with the application of tannic acid light filters in four acid lakes in northern Michigan, USA (Pillsbury \& Lowe, 1999). He found that light accounted for most of the variation in biomass and community structure with high light environment favoring filamentous green algae (Zygnematales) and low light favoring desmids and diatoms. Marks (1990) manipulated light and nutrients simultaneously in a three-way factorial design in oligotrophic Flathead Lake, Montana, USA. While nitrogen and phosphorus together significantly increased algal biomass, light had little effect in this system (Marks \& Lowe, 1993).

\section{Disturbance}

The influence of physical flow-mediated disturbance on benthic algal community structure was recently reviewed by Peterson (1996). Although not addressing this topic directly, a few students at Bowling Green did pursue aspects of this phenomenon. Lamb (1983) employed scanning electron microscopy to investigate the role of current in shaping algal community physiognomy. The publication resulting from his thesis (Lamb \& Lowe, 1987) was awarded the best paper of the year in the Ohio Journal of Science.

Barnese (1989) examined diel patterns of algal drift in the Maple River, Michigan, USA and found that disturbance caused by benthic insect activity partially explained patterns of algal drift (Barnese \& Lowe, 1992). Francoeur (1997) studied mechanisms of periphyton disturbance-resistance in a disturbance-prone river in New Zealand. He found that imbricated microform bed clusters of stones served as refugia for disturbance-vulnerable species (Francoeur et al., 1998). These refugia serve as epicenters for post-disturbance re-colonization of the stream by both periphyton and invertebrates. It is important to remember that nutrient resources and disturbance do not operate in isolation from each other and there may be interactive effects. Resource stress can alter the impact of hydrological disturbance on periphyton communities (Biggs et al., 1999). Biggs et al. (1998b) developed a habitat matrix model that considered the simultaneous impacts of nutrient abundance and disturbance intensity/ frequency. The model predicted responses of several common stream periphyton species and was later successfully tested on three valley segments of a New Zealand grassland river (Biggs et al., 1998a).

\section{Grazers}

Grazers can strongly influence the structure, density and physiology of periphytic algal communities (Steinman, 1996). Grazer-periphyton interactions have been the focus of several research investigations by students and collaborators at Bowling Green. The impact of grazing snails was a focus in of Lowe and Hunter (1988) who examined the impact of Physa integra on periphyton communities in Spring Lake, Michigan and by Barnese et al. (1990) who examined radular ultrastructure and grazing efficiency of six sympatric snails in Douglas Lake, Michigan. Barnese's investigation demonstrated the capability of the prostrate green alga Coleochaete orbicularis to resist grazing by snails. The thallus often lost erect colorless setae to snails but the prostrate chlorophyll-bearing cells remained largely intact. Further, benthic diatoms associated with the thallus of Coleochaete also often escaped predation. In further research in Douglas Lake, Marks and Lowe (1989) investigated the independent and interactive effects of snail grazing (Elimia livescens) and nutrient enrichment on structuring periphyton communities. Grazing had a more pronounced effect on algal community composition on the nutrientenriched substrates than on the controls. Grazing caused a decrease in periphyton diversity and an increase in the relative proportion of green algae, especially Stigeoclonium tenue. Gresens and Lowe (1994) also working in Douglas Lake manipulated periphyton patches with nutrient-diffusing substrates to examine patch preference by the grazing larva of the chironomid Paratanytarsus dubius. As with Marks \& Lowe (1989), addition of nitrogen and 
phosphorus resulted in a Stigeoclonium-dominated community, which was negatively correlated with Paratanytarsus grazing. Grazing preference was correlated positively, however, with algal diversity.

Two stream studies in which nutrients and grazers were manipulated illustrated the impact that grazers can exert on periphyton communities often greatly dampening the expected biomass increase of periphyton from nutrient stimulation. In the Maple River in northern Michigan Pan \& Lowe (1995) found that colonization of benthic substrates by hydropsychid caddisflies can have a stronger impact on periphyton accrual than nutrients. Biggs \& Lowe (1994) described the same phenomenon in the Kakanui River in New Zealand when the grazing snail Potamopyrgus antipodarum negated the effects of expected biomass accrual from nutrient addition.

\section{Environmental assessment}

The recent literature is rife with examples of the application of algae as tools for monitoring environmental quality both present (Lowe \& Gale, 1980; Lowe, 1981; Shubert, 1984; Stevenson \& Lowe, 1986; Whitton et al., 1991; Whitton \& Rott, 1995; Lowe \& Pan, 1996; Stevenson \& Pan, 1999) and past (Battarbee et al., 1999; Bradbury, 1999; Fritz et al., 1999). The value of algae as integrators of fluctuating environmental variables is well established and documented. This application has been a continuing interest to students in the algae laboratory at Bowling Green (McCullough, 1971; Rohr, 1977; Maurice, 1982; Karl, 1983; Blake, 1987; Passy, 1997; Gooden, 2002).

Algae are excellent integrators of fluctuating abiotic variables but these variables must be measured at correct temporal and spatial scales. Initial studies at Bowling Green were focused on local systems. For example, impact of treated domestic sewage on the Portage River, Ohio was the first research initiative using algae as environmental indicators at Bowling Green (Lowe \& McCullough, 1974). Our research group initially focused on aquatic environments near Bowling Green. Pryfogle and Lowe (1979) authored a methodology manuscript based on some of the initial findings and experiences with periphyton monitoring. In the 1970s, Stevenson (1976), Pryfogle (1976), Kline (1975) and others were focused on research projects in the Sandusky River watershed (Ohio). This was a particularly fertile time in this research group and led to Stevenson developing some of his early thought on environmental monitoring (Stevenson \& Pryfogle, 1976; Stevenson, 1984). Stevenson has now become a leading authority on the application of algae for water quality monitoring.

In the 1990s the laboratory established research collaboration with Procter and Gamble Experimental Stream Facility near Cincinnati, Ohio. In this controlled environment many synthetic chemicals and particularly surfactants were tested for their potential impact on benthic algal communities (Belanger et al., 1994). This collaboration provided us with the opportunity not for only bioassay research (Belanger et al., 1996), but also facilitated periphyton research not directly related to the bioassays (Lowe et al. 1996; Greenwood et al., 1999).

These integrated research activities continue with a new cadre' of graduate advisees researching and learning the roles of systematics, ecology and environmental assessment.

\section{Acknowledgements and concluding remarks}

This manuscript is dedicated to Dr. John C. Kingston my first doctoral advisee who succumbed to a brain tumor in 2004. John will forever stand as a shining example of a productive scientist who maintained balance in his life between science, his family, music and nature. I thank all of my graduate advisees, current and future without whom most of this research would never have happened. I thank especially R. Jan Stevenson and Yangdong Pan for supplying the inertia necessary for this event to happen. I thank my collaborators who have enriched my career. Finally, I thank John Dodd, who served as an important role model for teaching and advising students. Dodd wrote an article on this topic that strongly influenced me, "Science, a Modern Fountain for Youth" (Dodd, 1953). This little two-page paper is of a sort that is often undervalued by readers expecting "hard science" from science writers, but the manuscript outlined Dodd's approach to teaching and training students. I have tried to incorporate Dodd's ideas in my teaching 
approach. Dodd asks the following questions in equating teaching of science as a "fountain for youth." " 1 . Is the water in your fountain always clear and sparkling? Do students become thirsty just watching it? 2. Is it free from any taint of bias, boredom or bunk? 3. Is the pressure adjustable, so students can drink their fill without choking or without becoming disgusted because it flows too slowly? 4. Do you shut the fountain off at four o'clock sharp? 5. Can you accept the fact that most of the water goes down the drain, and console yourself with the thought that the little which is imbibed has important metabolic implications? 6. Do you have enough well-springs of information so the fountain never runs dry? 7. Are you patient with the eager ones who always manage to fall into the fountain? 8 . Can you recognize the timid ones who are desperately thirsty but are unable to crowd around a busy fountain? 9. And, finally, do you ever take a little drink yourself, just to see if the stuff is as advertised?' Thanks again, John.

\section{References}

Acker, F., 1977. The phytoplankton of the Maumee River between Grand Rapids, Ohio and Maumee, Ohio. Masters Thesis, Bowling Green State University, Bowling Green, Ohio, USA, 90 pp.

Bahls, L. L., 1973. Diatom community response to primary wastewater effluent. Journal of the Water Pollution Control Federation 45: 134-144.

Bahls, P. A. \& L. L. Bahls, 1974. Trophic response to a hatchery effluent. Proceedings of the Montana Academy of Science 34: 5-11.

Barnese, L. E., 1989. A survey and experimental study of algal drift in the Maple River, Pellston, Michigan. Doctoral Dissertation, Bowling Green State University, Bowling Green, Ohio, USA, 124 pp.

Barnese, L. E. \& R. L. Lowe, 1992. Effects of substrate, light and benthic invertebrates on algal drift in small streams. Journal of the North American Benthological Society 11: 49-59.

Barnese, L. E., R. L. Lowe \& R. D. Hunter, 1990. Comparative grazing efficiency of six species of sympatric snails in Douglas Lake, Michigan. Journal of the North American Benthological Society 9: 35-44.

Battarbee, R. W., D. F. Charles, S. S. Dixit \& I. Renberg, 1999. Diatoms as indicators of surface water acidity. In Stoermer, E. F. \& J. P. Smol (eds), The Diatoms: applications for the Environmental and Earth Sciences. Cambridge University Press, 85-127.

Belanger, S. E., J. B. Barnum, D. M. Woltering, J. W. Bowling, R. M. Ventullo, S. D. Schermerhorn \& R. L. Lowe, 1994.
Algal periphyton structure and function in response to consumer chemicals in stream mesocosms. In Graney, R. L., J. H. Kennedy \& J. H. Rogers (eds), Aquatic Mesocosm Studies in Ecological Risk Assessment. SETAC Special Publication Series Lewis Publishers, Boca Ratan, FL: 535-567.

Belanger, S. E., R. L. Lowe \& B. H. Rosen, 1985. Epiphytism of Synedra parasitica on Surirella robusta: observations of populations and associations in a Virginia pond. Transactions of the American Microscopical Society 104: 378-386.

Belanger, S. E., K. L. Rupe, R. L. Lowe, D. W. Johnson \& Y. Pan, 1996. A flow through laboratory microcosm for assessing effects of surfactants on natural periphyton. Environmental Toxicology and Water Quality 11: 65-76.

Biggs, B. J. F., 1989. Biomonitoring of organic pollution using periphyton, South Branch, Canterbury, New Zealand. New Zealand Journal of Marine and Freshwater Research 23: 263-274.

Biggs, B. J. F. \& R. L. Lowe, 1994. Responses of two trophic levels to patch enrichment along a New Zealand stream continuum. New Zealand. New Zealand Journal of Marine and Freshwater Research 28: 119-134.

Biggs, B. J. F., C. Kilroy \& R. L. Lowe, 1998a. Periphyton development in three valley segments of a New Zealand grassland river: test of a habitat matrix conceptual model within a catchment. Archive für Hydrobiologie 143: 147-177.

Biggs, B. J. F., R. J. Stevenson \& R. L. Lowe, 1998b. A habitat matrix conceptual model for stream periphyton. Archive für Hydrobiologie 143: 21-56.

Biggs, B. J. F., N. Tuchman, R. L. Lowe \& R. J. Stevenson, 1999. Resource stress alters hydrological disturbance effects in a stream periphyton community. Oikos 85: 95-108.

Blake, G., 1987. The effects of the agricultural herbicide alachlor on total biomass and community structure of algal periphyton in artificial streams. Masters Thesis, Bowling Green State University, Bowling Green, Ohio, USA, 97 pp.

Bradbury, J. P., 1999. Continental diatoms as indicators of long-term environmental change. In Stoermer, E. F. \& J. P. Smol (eds), The Diatoms: applications for the environmental and Earth Sciences. Cambridge University Press, 169-182.

Bruno, M. G., 1978. Distribution and periodicity of desmids and diatoms in a Northwestern Ohio bog lake. Masters Thesis, Bowling Green State University, Bowling Green, Ohio, USA, 64 pp.

Bruno, M. G. \& R. L. Lowe, 1980. Differences in the distribution of some bog diatoms: a cluster analysis. American Midland Naturalist 104: 70-79.

Busch, D. E., 1974. Ultrastructure of the filamentous habit in the diatom Navicula confervacea (Kütz.) Grun. Journal of Phycology 10: 241-243.

Camburn, K. E., 1977. The haptobenthic diatom flora of Long Branch Creek, South Carolina. Masters Thesis, Bowling Green State University, Bowling Green, Ohio, USA, 266 pp.

Camburn, K. E., R. L. Lowe \& D. E. Stoneburner, 1978. The haptobenthic diatom flora of Long Branch, South Carolina. Nova Hedwigia 37: 149-279.

Carrick, H. J., 1985. The response of Lake Michigan benthic algae to an in situ nutrient manipulation. Masters Thesis, 
Bowling Green State University, Bowling Green, Ohio, USA, $86 \mathrm{pp}$.

Carrick, H. J. \& R. L. Lowe, 1988. Response of Lake Michigan benthic algae to in situ enrichment with Si, N and P. Canadian Journal of Fisheries and Aquatic Science 45: 271-279.

Carrick, H. J., R. L. Lowe \& J. T. Rotenberry, 1988. Functional associations of benthic algae along experimentally manipulated nutrient-gradients: Relationships with algal community diversity. Journal of the North American Benthological Society 7: 117-128.

Carrick, H. J. \& R. L. Lowe, 1989. Benthic algal response to N and $\mathrm{P}$ enrichment along a $\mathrm{pH}$ gradient. Hydrobiologia 179: 119-127.

Descy, J. P., 1979. A new approach to water quality estimation using diatoms. Nova Hedwigia Beihefte 64: 305-323.

DeYoe, H. R., R. L. Lowe \& J. C. Marks, 1992. The effect of nitrogen and phosphorus on the endosymbiont load of Rhopalodia gibba and Epithemia turgida (Bacillariophyceae). Journal of Phycology 28: 773-777.

Dixit, S. S., B. F. Cumming, J. P. Smol \& J. C. Kingston, 1992. Monitoring environmental changes in lakes using algal microfossils. In McKenzie, D. H., D. E. Hyatt \& V. J. MacDonald (eds), Ecological Indicators. Elsevier Applied Sciences, Amsterdam: 1135-1155.

Dodd, J. D., 1953. Science, a modern fountain for youth. American Biology Teacher 15: 1-2.

Fairchild, F. W. \& R. L. Lowe, 1984. Algal substrates which release nutrients: effects on periphyton and invertebrate succession. Hydrobiologia 114: 29-37.

Fairchild, G. W., R. L. Lowe \& W. B. Richardson, 1985. Nutrient-diffusing substrates as an in situ bioassay using periphyton: Algal growth responses to combinations of $\mathrm{N}$ and P. Ecology 66: 465-472.

Fisher, D. Z., 1980. Autumn periphyton and phytoplankton diatom communities in relation to depth and current velocity in the Maumee River, Ohio. Masters Thesis, Bowling Green State University, Bowling Green, Ohio, USA, 86 pp.

Francoeur, S. N., 1997. Microform bed clusters as refugia for periphyton in a flood-prone headwater stream. Masters Thesis, Bowling Green State University, Bowling Green, Ohio, USA, 34 pp.

Francoeur, S. N., B. J. F. Biggs \& R. L. Lowe, 1998. Microform bed clusters as refugia for periphyton in a flood-prone headwater stream. New Zealand Journal of Marine and Freshwater Research 32: 363-374.

Fritz, S. C., B. F. Cumming, F. Gassee \& K. R. Laird, 1999. Diatoms as indicators of hydrologic and climate change in saline lakes. In Stoermer, E. F. \& J. P. Smol (eds), The Diatoms: Applications for the Environmental and Earth Sciences. Cambridge University Press, 41-72.

Gomez, S. R., J. R. Johansen \& R. L. Lowe, 2003. Epilithic aerial algae of Great Smoky Mountains National Park. Biologia Bratislavia 58: 603-615.

Gooden, W., 2002. Periphyton responses to surfactants: Community structure and mat architecture. Doctoral Dissertation, Bowling Green State University, Bowling Green, Ohio, USA, $220 \mathrm{pp}$

Greenwood, J. L., T. A. Clason, R. L. Lowe \& S. E. Belanger, 1999. Examination of endopelic and epilithic algal commu- nity structure employing scanning electron microscopy. Freshwater Biology 41: 821-828.

Gresens, S. E. \& R. L. Lowe, 1994. Periphyton patch preference in grazing chironomid larvae. Journal of the North American Benthological Society 13: 89-99.

Jackson, D. C., 1975. Distribution and morphology of members of the diatom genera Gyrosigma Hassal and Pleurosigma W. Smith in the Portage River Drainage System. Masters Thesis, Bowling Green State University, Bowling Green, Ohio, USA, 75 pp.

Jackson, D. C. \& R. L. Lowe, 1978. Valve ultrastructure of species of the diatom genera Gyrosigma Hassal and Pleurosigma W. Sm. from the Portage River Drainage system, Ohio. Transactions of the American Microscopical Society 97: 569-581.

Johansen, J. R., R. L. Lowe, S. R. Gomez, J. P. Kociolek \& S. A. Makosky, 2004. New algal species records for the Great Smoky Mountains National Park, U.S.A., with an annotated checklist of all reported algal species for the park. Algological Studies.

Kaatz, M. R., 1955. The black swamp: a study in historical geography. Annals of the Association of American Geographers 45: $1-35$.

Karl, K. A., 1983. The effects of fly ash extract on periphyton community structure in field enclosures. Masters Thesis, Bowling Green State University, Bowling Green, Ohio, USA, $97 \mathrm{pp}$

Keithan, E. D., 1983. Primary productivity and structure of phytolithic communities in streams in the Great Smoky Mountains National Park. Doctoral Dissertation, Bowling Green State University, Bowling Green, Ohio, USA, 83 pp.

Keithan, E. D. \& R. L. Lowe, 1985. Primary productivity and structure of phytolithic communities in streams in the Great Smoky Mountains National Park. Hydrobiologia 123: 59-67.

Keithan, E. D., R. L. Lowe \& H. DeYoe, 1988. Benthic diatom distribution in a Pennsylvania stream: the role of $\mathrm{pH}$ and nutrients. Journal of Phycology 24: 581-585.

Kilroy, C., K. Sabbe, E. Bergy, W. Vyverman \& R. Lowe, 2003. New species of Fragilariforma (Bacillariophyceae) from New Zealand and Austrailia. New Zealand Journal of Botany 41: 535-554.

Kingston, J. C., 1980. Characterization of benthic diatom communities in Grand Traverse Bay, Lake Michigan. Doctoral Dissertation, Bowling Green State University, Bowling Green, Ohio, USA.

Kingston, J. C., R. L. Lowe, E. F. Stoermer \& T. Ladewski, 1983. Spatial and temporal distribution of benthic diatoms in northern Lake Michigan. Ecology 64: 1566-1580.

Kline, P. A., 1975. Survey of the phytoplankton of the Sandusky River at Fremont, Sandusky Co., Ohio. Masters Thesis, Bowling Green State University, Bowling Green, Ohio, USA.

Kline, P. E. \& R. L. Lowe, 1976. Phytoplankton of the Sandusky River near Fremont, Ohio. In Baker, D. \& B. Prater (eds), Proceedings of the Sandusky River Basin Symposium . United States Environmental Protection Agency, 175-208.

Kociolek, J. P., 1982. Diatoms from two streams in Great Smoky Mountains National Park. Masters Thesis, Bowling Green State University, Bowling Green, Ohio, USA, 175 pp. 
Kociolek, J. P., M. A. Lamb \& R. L. Lowe, 1983. Notes on the growth and ultrastructure of Biddulphia laevis Ehr. (Bacillariophyceae) in the Maumee River, Ohio. Ohio Journal of Science 8: 125-130

Kociolek, J. P. \& R. L. Lowe, 1983. Scanning electron microscopic observations on the frustular morphology and filamentous growth habit of Diatoma hiemale v. mesodon. Transactions of the American Microscopical Society 102: 281-287.

Kociolek, J. P. \& E. F. Stoermer, 2001. Taxonomy and ecology: a marriage of necessity. Diatom Research 16: 433-442.

Krejci, M., 1985. Spatial patterns of epipsammic diatoms in a spring-fed brook with emphasis on the effect of sand grain mineralogy on diatom occurrence. Doctoral Dissertation, Bowling Green State University, Bowling Green, Ohio, USA.

Krejci, M. E. \& R. L. Lowe, 1986. The importance of sand grain mineralogy and topography in determining microspatial distribution of epipsammic diatoms. Journal of the North American Benthological Society 5: 221-229.

Krejci, M. E. \& R. L. Lowe, 1987a. Spatial and temporal variation of epipsammic diatoms in a spring-fed brook. Journal of Phycology 23: 585-590.

Krejci, M. E. \& R. L. Lowe, 1987b. The seasonal occurrence of macroscopic colonies of Meridion circulare (Bacillariophyceae) in a spring-fed brook. Transactions of the American Microscopical Society 106: 173-178.

Lamb, M. E., 1983. The effects of current velocity on the structuring of diatom communities. Masters Thesis, Bowling Green State University, Bowling Green, Ohio, USA, 94 pp.

Lamb, M. A. \& R. L. Lowe, 1987. Effects of current velocity on the physical structuring of diatom (Bacillariophyceae) communities. Ohio Journal of Science 87: 72-78.

Lamb, M. A. \& R. L. Lowe, 1981. A preliminary investigation of the effect of current speed on periphyton community structure. Micron 12: 211-212.

Lowe, R. L., 1975. Comparative ultrastructure of the valves of some species of Cyclotella (Bacillariophyceae). Journal of Phycology 11: 415-424.

Lowe, R. L., 1981. The utility of diatoms for hazard assessment of chemicals in ecosystems. Special Publication of the National Academy of Science, Washington, DC, pp 133-136.

Lowe, R. L. \& D. E. Busch, 1975. Morphological observations on two species of the diatom genus Thalassiosira from freshwater habitats in Ohio. Transactions of the American Microscopical Society 94: 118-123.

Lowe, R. L. \& R. E. Crang, 1972. The ultrastructure and morphological variability of the frustule of Stephanodiscus invisitatus Hohn and Hellerman. Journal of Phycology 8: 256-259.

Lowe, R. L. \& W. F. Gale, 1980. Monitoring periphyton with artificial benthic substrates. Hydrobiologia 69: 235-244.

Lowe, R. L. \& R. D. Hunter, 1988. The effect of grazing by Physa integra on periphyton community structure. Journal of the North American Benthological Society 7: 29-36.

Lowe, R. L. \& P. E. Kline, 1976. Planktonic centric diatoms of the Sandusky River near Fremont, Ohio. In Baker, D. B. Prater (eds), Proceedings of the Sandusky River Basin Symposium. United States Environmental Protection Agency: $143-152$.
Lowe, R. L. \& J. P. Kociolek, 1984. New and rare diatoms from Great Smoky Mountains National Park. Nova Hedwigia 39: 465-276.

Lowe, R. L., S. Golladay \& J. Webster, 1986. Periphyton response to nutrient manipulation in a clear-cut and forested watershed. Journal of the North American Benthological Society 5: 211-220.

Lowe, R. L., J. B. Guckert, S. E. Belanger, D. H. Davidson \& D. W. Johnson, 1996. An Evaluation of Periphyton Community Structure and Function on Tile and Cobble Substrata in Experimental Stream Mesocosms. Hydrobiologia 328: 135-146.

Lowe, R. L. \& J. M. McCullough, 1974. The effect of sewage treatment plant effluent on diatom communities in the Portage River, Wood Co., Ohio. Ohio Journal of Science 74: 154-161.

Lowe, R. L. \& Y. Pan, 1996. Use of Benthic Algae in Water Quality Monitoring. In Stevenson, R. J., M. L. Bothwell \& R. L. Lowe (eds), Benthic Algal Ecology in Freshwater Ecosystems. Academic Press, San Diego, CA, USA: 705-739.

Lowe, R. L., B. H. Rosen \& J. C. Kingston, 1982. A comparison of epiphytes on Bangia atropurpurea (Rhodophyta) and Cladophora glomerata (Chlorophyta) from Northern Michigan. Journal of Great Lakes Research 8: 164-168.

Luttenton, M. R., 1989. In situ manipulation of factors affecting periphyton community structure. Doctoral Dissertation, Bowling Green State University, Bowling Green, Ohio, USA.

Marks, J. C., 1990. The independent and interactive effects of nitrogen, phosphorus and light on structuring periphyton in Flathead Lake, Montana. Masters Thesis, Bowling Green State University, Bowling Green, Ohio, USA, 92 pp.

Marks, J. C. \& R. L. Lowe, 1989. The independent and interactive effects of snail grazing and nutrient enrichment on structuring periphyton communities. Hydrobiologia 185: 9-17.

Marks, J. C. \& R. L. Lowe, 1993. Interactive effects of nutrient availability and light levels on the periphyton composition of a large oligotrophic lake. Canadian Journal of Fisheries and Aquatic Science 50: 1270-1278.

Maurice, C. G., 1982. Effects of acidification on the periphyton of an artificial stream. Masters Thesis, Bowling Green State University, Bowling Green, Ohio, USA, 92 pp.

McCullough, J. M., 1971. The effect of sewage-treatment-plant effluent on diatom communities in the North Branch of the Portage River, Wood County, Ohio. Masters Thesis, Bowling Green State University, Bowling Green, Ohio, USA, 75 pp.

Miller, A. R., 1983. Temporal and spatial relationships in the epipsammic diatom community. Masters Thesis, Bowling Green State University, Bowling Green, Ohio, USA, 87 pp.

Miller, A. R., R. L. Lowe \& J. T. Rotenberry, 1987. Microsuccession of diatoms on sand grains. Journal of Ecology 75: 693-709.

Millie, D. F. \& R. L. Lowe, 1983. Studies on Lake Erie's littoral algae; host specificity and temporal periodicity of epiphytic diatoms. Hydrobiologia 99: 7-18.

Morgan, M. D., 1987. Impact of nutrient enrichment and alkalinization on periphyton communities in the New Jersey Pine Barrens. Hydrobiologia 144: 233-241. 
Pan Y., 1993. The effects of nutrients on periphyton. Doctoral Dissertation, Bowling Green State University, Bowling Green, Ohio, USA, 98 pp.

Pan, Y. \& R. L. Lowe, 1995. The effects of hydropsychid colonization on algal response to nutrient enrichment in a small Michigan stream, U.S.A. Freshwater Biology 33: 393-400.

Passy, S. I., 1997. Ecology and systematics of the periphytic diatoms from the Mesta River system, Bulgaria. Doctoral Dissertation, Bowling Green State University, Bowling Green, Ohio, USA, 241 pp.

Passy, S. I. \& R. L. Lowe, 1994. Taxonomy and ultrastructure of Gomphoneis mesta sp. nov. (Bacillariophyta), a new epilithic diatom from the Mesta River, Bulgaria. Journal of Phycology 30: 885-891.

Passy-Tolar, S. I., J. P. Kociolek \& R. L. Lowe, 1997. New Gomphonema species (Bacillariophyta) from South African rivers. Journal of Phycology 33: 455-474.

Passy-Tolar, S. I., Y. Pan \& R. L. Lowe, 1999. Ecology of the major periphytic diatom communities from the Mesta River, Bulgaria. International Review der Gesempten Hydrobiologie 84: 129-174.

Peterson, C. G., 1996. Response of benthic algal communities to natural physical disturbance. In Stevenson, R. J., M. L. Bothwell \& R. L. Lowe (eds), Benthic Algal Ecology in Freshwater Ecosystems. Academic Press, San Diego, CA, USA: $375-402$.

Pillsbury, R. W., 1993. Factors influencing the structure of benthic algal communities in acid lakes. Doctoral Dissertation, Bowling Green State University, Bowling Green, Ohio, USA, $142 \mathrm{pp}$

Pillsbury, R. W. \& R. L. Lowe, 1999. The response of benthic algae to manipulations of light resources in four acidic lakes in northern Michigan. Hydrobiologia 394: 69-81.

Potapova, M. G., K. C. Ponader, R. L. Lowe, T. A. Clason \& L. A. Bahls, 2003. Small-celled Nupela species from U.S.A. rivers. Diatom Research. 18: 293-306.

Pryfogle, P. A., 1976. Seasonal distribution of periphytic diatoms on natural substrates in Tymochtee Creek. Masters Thesis, Bowling Green State University, Bowling Green, Ohio, USA, $79 \mathrm{pp}$.

Pryfogle, P. A. \& R. L. Lowe, 1979. Sampling and interpretation of epilithic lotic diatom communities. In Weitzel, R. (ed.), Methods and Measurements of Attached Microcommunities: A Review. American Society for Testing and Materials, Philadelphia, PA, USA: 77-89.

Rohr, J. L., 1977. Changes in diatom community structure due to environmental stress. Masters Thesis, Bowling Green State University, Bowling Green, Ohio, USA, 157 pp.

Sabbe, K., K. Vanhoutte, R. L. Lowe, E. A. Bergey B. J. F. Biggs, S. Francoeur, D. Hodgson \& W. Vyverman, 2001. Six new Actinella (Bacillariophyta) species from Papua New Guinea, Australia and New Zealand: further evidence for widespread diatom endemism in the Australasian region. European Journal of Phycology 36: 321-340.

Sharkey, M. J., 2001. The all taxa biological inventory of the Great Smoky Mountains National Park. Florida Entomologist 84: 556-564.

Shubert, L. E., 1984. Algae as Ecological Indicators . Academic Press, London, England 434.
Steinman, A. D., 1996. Effects of grazers on freshwater benthic algae. In Stevenson, R. J., M. L. Bothwell \& R. L. Lowe (eds), Benthic Algal Ecology in Freshwater Ecosystems. Academic Press, San Diego, CA, USA: 341-373.

Stevenson, R. J., 1976. The periphytic diatoms of the Sandusky River. Masters Thesis, Bowling Green State University, Bowling Green, Ohio, USA, 114 pp.

Stevenson, R. J., 1984. Epilithic and epipelic diatoms in the Sandusky River, with emphasis on species diversity and water quality. Hydrobiologia 114: 161-175.

Stevenson, R. J. \& R. L. Lowe, 1986. Sampling and interpretation of algal patterns for water quality assessments. In Isom, B. G. (ed.), Rationale for Sampling and Interpretation of Ecological Data in the Assessment of Freshwater Ecosystems American Society for Testing and Materials. Philadelphia, PA, USA: 118-149.

Stevenson, R. J. \& Y. Pan, 1999. Assesing environmental conditions in rivers and streams with diatoms. In Stoermer, E. F. \& J. P. Smol (eds), The Diatoms: Applications for the Environmental and Earth Sciences. Cambridge University Press, 11-40.

Stevenson, R. J. \& P. A. Pryfogle, 1976. A comparison of the winter diatom flora of the Sandusky River and Tymochtee Creek. In Baker, D. \& B. Prater (eds), Proceedings of the Sandusky River Basin Symposium. United States Environmental Protection Agency, 209-231.

Whitton, B. A., E. Rott \& G. Friedrich, 1991. Use of Algae for Monitoring Rivers. E. Rott, Publisher, Institut für Botanik, AG Hydrobotanik, Universität Innsbruck, A-6020 Innsbruck, Austria, 193 pp.

Whitton, B. A. \& E. Rott, 1995. Use of algae for monitoring rivers II. E. Rott, Publisher, Institut für Botanik, AG Hydrobotanik, Universität Innsbruck, A-6020 Innsbruck, Austria. 196 pp.

\section{Appendix 1}

Graduate theses and dissertations from the Bowling Green State University Algae Laboratory, 1971-2003.

1. J. Michael McCullough, M. A., 1971. The effect of sewage-treatment-plant effluent on diatom communities in the North Branch of the Portage River, Wood County, Ohio.

2. Robert Reitz, M. S., 1973. Phytoplankton periodicity in two Northwestern Ohio ponds.

3. Bill Brower, M. S., 1973. Phytoplankton and periphyton diatom relationships in two highly eutrophic lakes.

4. David E. Busch, M. S., 1974. Vertical and seasonal distribution of the Bacillariophyta in the Miller Blue Hole, Sandusky Co., Ohio. 
5. Terrance L. Breyman, M. S., 1974. Bangia in Western Lake Erie.

6. David C. Jackson, M. S., 1975. Distribution and morphology of members of the diatom genera Gyrosigma Hassal and Pleurosigma W. Smith in the Portage River Drainage System.

7. Phillip A. Kline, M. S., 1975. Survey of the phytoplankton of the Sandusky River at Fremont, Sandusky Co., Ohio. BGSU.

8. Ronald J. Bockelman, M. S., 1975. The seasonal productivity of zooplankton and benthic macroinvertebrate populations in six northwest Ohio ponds.

9. R. Jan Stevenson, M. S., 1976. The periphytic diatoms of the Sandusky River.

10. P.A. Pryfogle, M. S., 1976. Seasonal distribution of periphytic diatoms on natural substrates in Tymochtee Creek.

11. Keith Camburn, M. S., 1977. The haptobenthic diatom flora of Long Branch Creek, South Carolina.

12. Frank Acker, M. S., 1977. The phytoplankton of the Maumee River between Grand Rapids, Ohio and Maumee, Ohio.

13. J. L. Rohr, M. S., 1977. Changes in diatom community structure due to environmental stress.

14. R. F. Andritsch, M. S., 1977. Seasonal photosynthetic rates of Chara globularis in Steidtmann Pond.

15. Mary Bruno, M. S., 1978. Distribution and periodicity of desmids and diatoms in a Northwestern Ohio bog lake.

16. David F. Millie, M. S., 1979. An analysis of epiphytic diatom assemblages of three species of aquatic vascular plants in three Lake Erie marshes.

17. Robert Foster, M. S., 1980. Selected toxic metal concentrations in several species of western Lake Erie fish with respect to age.

18. Daniel Z. Fisher, M. S., 1980. Autumn periphyton and phytoplankton diatom communities in relation to depth and current velocity in the Maumee River, Ohio.

19. John C. Kingston, Ph.D., 1980. Characterization of benthic diatom communities in Grand Traverse Bay, Lake Michigan.

20. Earl Chilton, M. S., 1982. A comparison of macroscopic invertebrates living in Bangia atropurpurea and Cladophora glomerata beds in Lake Erie.

21. John P. Kociolek, M. S., 1982. Diatoms from two streams in Great Smoky Mountains National Park.

22. Charles G. Maurice, M. S., 1982. Effects of acidification on the periphyton of an artificial stream.

23. David R. Beeson, M. S., 1982. Epiphytic diatom (Bacillariophyceae) community structure in a wetland continuum, Sugar Island, Michigan.

24. Barry H. Rosen, Ph.D., 1982. Physiological and ultrastructural responses to light intensity and nutrient limitation in the planktonic diatom Cyclotella meneghiniana.

25. Mark E. Lamb, M. S., 1983. The effects of current velocity on the structuring of diatom communities.

26. Ann R. Miller, M. S., 1983. Temporal and spatial relationships in the epipsammic diatom community.

27. Robert Genter, M. S., 1983. The effects of different initial colonists on the outcome of periphyton succession in a small stream.

28. Kevin A. Karl, M. S., 1983. The effects of fly ash extract on periphyton community structure in field enclosures.

29. Elaine D. Keithan, Ph.D., 1983. Primary productivity and structure of phytolithic communities in streams in the Great Smoky Mountains National Park.

30. Norlida Anis, M. S., 1985. Effects of water chemistry on the distribution of diatom communities.

31. Mark Krejci, Ph.D., 1985. Spatial patterns of epipsammic diatoms in a spring-fed brook with emphasis on the effect of sand grain mineralogy on diatom occurrence.

32. Hunter J. Carrick, M. S., 1985. The response of Lake Michigan benthic algae to an in situ nutrient manipulation.

33. Gail Blake, M. S., 1987. The effects of the agricultural herbicide alachlor on total biomass and community structure of algal periphyton in artificial streams.

34. Mark R. Luttenton, Ph.D., 1989. In situ manipulation of factors affecting periphyton community structure. 
35. Lisa E. Barnese, Ph.D., 1989. A survey and experimental study of algal drift in the Maple River, Pellston, Michigan.

36. Douglas Deutschman, M. S., 1990. Response of an algal community to temporal variability of resources.

37. Jane C. Marks, M. S., 1990. The independent and interactive effects of nitrogen, phosphorus and light on structuring periphyton in Flathead Lake, Montana.

38. Craig D. Layne, M. S., 1990. The algal mat of Douglas Lake, Michigan: Its composition, role in lake ecology, and response to chemical perturbations.

39. Hudson DeYoe, Ph.D., 1991. Preliminary characterization of the relationship between Rhopalodia gibba (Bacillariophyceae) and its cyanobacterial endosymbiont.

40. Susan Hardman, Ph.D., 1992. Environmental components influential in epipelic algal community structure.

41. James C. Sferra, M. S., 1992 Potential effects of the zebra mussel, Dreissena polymorpha (Pallas) on the Western Basin of Lake Erie.

42. Carmen Pedraza-Silva, M. S., 1992. A description of the algal floras of Guzmania berteroniana and Vriesia sintenisii (Bromeliaceae) and preliminary investigation of bromeliad-algal interactions.

43. Robert W. Pillsbury, Ph.D., 1993. Factors influencing the structure of benthic algal communities in acid lakes.

44. Diane Longanbach M. A. T., 1993. Survey of aquaria educational curricula across the United States.

45. Yangdong Pan, Ph.D., 1993. The effects of nutrients on periphyton.

46. LouAnne Reich, M. S., 1994. An examination of Douglas Lake, Cheboygan County, Michigan as suitable habitat for the zebra mussel (Dreissena polymorpha): food quality and attachment site preference.

47. Bret Gargasz, M. S., 1994. Non-thesis, plan II.

48. Steven Francoeur, M. S., 1997. The effect of in-stream flow refugia on the recovery of stream periphyton communities following flooding disturbance.

49. Sophia Passy, Ph.D., 1997. Ecology and systematics of the periphytic diatoms from the Mesta River system, Bulgaria.

50. Joanne Rhoers, M. S., 1997. The Impact of the Crayfish Orconectes propinquis on Benthic Algae and Zebra Mussels.

51. Rebecca Visnyai, M. S., 1997. Wetland restoration: the need to base restoration on function and landscape-level processes.

52. Randy Litteral, 1998. Benthic algal community structure and the compensation point.

53. Jennifer L. Greenwood, M. S., 1998. The effects of $\mathrm{pH}$ light on periphyton communities in a Michigan Wetland.

54. Todd A. Clason, M. S., 1999. Diurnal migration and community ultrastructure of benthic algae in Douglas Lake.

55. Timothy Stewart, Ph.D., 1999. Evidence and mechanisms for Dreissena effects on other benthic macroinvertebrates in western Lake Erie.

56. Julianne Heinlein, M. S., 2000. Flood disturbance mechanisms in stream periphyton: individual and interactive effects of shear stress perterbations and suspended sediment concentration.

57. Agnieszka Pinowska, Ph.D., 2001. Indirect effect of sediment nutrient enrichment on epiphytic algal communities.

58. Amy Kireta, M. S., 2001. Benthic algal shifts in response to the round goby.

59. Wanda Gooden, Ph.D., 2002. Periphyton responses to surfactants: Community structure and mat architecture.

60. Jennifer Ress, M. S., 2003. Comparative grazing efficiencies of three aquatic grazers and their impact on periphyton recovery.

61. Jennifer Wearly, M. S., 2004. Changes in algal communities due to zebra mussel invasion of an oligotrophic inland lake.

62. Sarah Zeiler, M. S., 2004. The ratio of periphyton to plankton under variable nutrient regimens in a fen peatland. 